Article

\title{
Simultaneous Application of Biosurfactant and Bioaugmentation with Rhamnolipid-Producing Shewanella for Enhanced Bioremediation of Oil-Polluted Soil
}

\author{
Manoharan Melvin Joe ${ }^{1, *(1)}$, Ram Gomathi ${ }^{1, *}$, Abitha Benson ${ }^{2}$, Devaraj Shalini ${ }^{1}$, \\ Parthasarathi Rengasamy ${ }^{3}$, Allen John Henry ${ }^{1}$, Jaak Truu ${ }^{4, *}$, Marika Truu ${ }^{4}$ and Tongmin Sa ${ }^{5}$ \\ 1 Department of Microbiology, School of Life Sciences, VELS University, Velan Nagar, Pallavaram, \\ Chennai 600117, Tamilnadu, India \\ 2 Department of Biotechnology, School of Life Sciences, VELS University, Velan Nagar, Pallavaram, \\ Chennai 600117, Tamilnadu, India \\ 3 Department of Microbiology, Faculty of Agriculture, Annamalainagar 608002, Tamilnadu, India \\ 4 Institute of Molecular and Cell Biology, University of Tartu, Riia 23, EE51010 Tartu, Estonia \\ 5 Department of Environmental and Biological Chemistry, Chungbuk National University, \\ Cheongju 28644, Korea \\ * Correspondence: micromelvin@gmail.com (M.M.J.); gomathitkc@gmail.com (R.G.); jaak.truu@ut.ee (J.T.); \\ Tel.: +91-739-584-1132 (M.M.J); +372-737-5021 (J.T.)
}

Received: 6 August 2019; Accepted: 30 August 2019; Published: 9 September 2019

\begin{abstract}
In the present study, a combined treatment strategy involving the addition of rhamnolipid, rhamnolipid-producing bacteria (Shewanella sp. BS4) and a native soil microbial community for the remediation of hydrocarbon-contaminated soil under pilot-scale conditions was adopted. The isolate BS4 (rhl+), demonstrating the highest emulsification activity and surface tension reduction efficiency, was identified based on $16 \mathrm{~S}$ rDNA sequencing as Shewanella sp. strain. Growth conditions for rhamnolipid production were optimized based on Central Composite Design (CCD) as $2.9 \%$ crude oil, a $54 \times 10^{6} \mathrm{CFU} \mathrm{g}{ }^{-1}$ inoculation load of soil, a temperature of $30.5^{\circ} \mathrm{C}$, and a $\mathrm{pH}$ of 6.7. In situ bioremediation experiments, conducted using hydrocarbon-contaminated soil treated with the combination of rhamnolipid and rhamnolipid-producing bacteria, showed that the inoculated Shewanella sp. BS4, along with the indigenous soil microbial community, supported the highest hydrocarbon-degrading bacterial population and soil respiration activity, and this treatment resulted in $75.8 \%$ hydrocarbon removal efficiency, which was higher compared to contaminated soil devoid of any treatment.
\end{abstract}

Keywords: bioremediation; biosurfactant; hydrocarbon-contaminated soil; rhamnolipids; Shewanella sp.

\section{Introduction}

Heavy dependence on petroleum products as a major energy source has led to the contamination of soils by oil-derived hydrocarbons to a great extent [1]. Soil contamination by hydrocarbons can be a result of an improper production process (i.e., oil spills from drilling), transport (i.e., oil spills from tankers or pipelines), storage (i.e., leaking storage tanks), or an improper disposal process. Soil hydrocarbon contamination can affect the functional equilibrium that exists between soil biota and their natural environment. Although numerous physicochemical remediation techniques can be applied to clean up oil-polluted soils, these techniques are expensive and disruptive [2]. The application of biological remediation techniques, such as biostimulation and bioaugmentation, as well 
as plant-assisted bioremediation for hydrocarbon-contaminated soils, offers generally cheaper and more environmentally friendly solutions for clean-up of polluted sites [3,4].

Though the use of different hydrocarbon-degrading bacteria, including Pseudomonas spp., for the bioremediation of hydrocarbon-contaminated soils, has been successfully implemented, the main problem these bio-degraders encounter is the low solubility and high hydrophobicity of the oil-derived pollutants [5] due to the fact that hydrocarbons are strongly bonded to soil particles and are not available to the bacteria [6]. In this context, the use of biosurfactants for the enhancement of the bioremediation of soil hydrocarbon contamination has been recommended due to their non-toxic nature and biodegradability with no compromise in foaming properties [7]. Biosurfactant application can increase the bacterial cell surface hydrophobicity, allowing the hydrophobic substrates to interact with bacterial cells more effectively [5]

Rhamnolipid-type biosurfactants belong to a group of anionic surfactants comprising of 1-(+)-rhamnose and $\beta$-hydroxyalkanoic acid units [8]. Pseudomonas aeruginosa is the most widely studied rhamnolipid-producing bacterium known for its ability to metabolize a variety of hydrophobic substrates, including n-alkanes, hexadecane, and oils [9]. Di-rhamnolipid synthesis in P. aeruginosa occurs in three consecutive enzymatic reactions: 3-(3-hydroxyalkanoyloxy) alkanoic acid (HAA) synthesis catalyzed by rhamnosyltransferase I (RhlA), a glycosyltransfer reaction catalyzed by glycosyltransferase $(R h l \mathrm{~B})$ to form mono-rhamnolipids, and the reaction catalyzed by rhamnosyltransferase II (RhlC) that yields di-rhamnolipids [10]. The first two enzymes encoded by $R h l \mathrm{~A}$ and $R h l \mathrm{~B}$ genes are both located in the RhlAB operon but are independently involved in rhamnolipid biosynthesis [11].

Studies on the combined use of rhamnolipids and rhamnolipid-producing bacterial strains for the bioremediation of hydrocarbon-contaminated soils are scarce; at the same time, their role in the remediation of crude oil-contaminated sites has been documented by many researchers [12-14]. Though much work has been conducted on rhamnolipid production focused on P. aeruginosa and other Pseudomonas strains, rhamnolipid production has also been reported for bacteria belonging to other genera, such as Acinetobacter [15,16] Enterobacter [16], Pantoea [16], and Serratia [17] Studies have shown that bioaugmentation is most efficient in cases when the augmented bacteria are inherent in the polluted soils $[3,18]$.

On 28 January 2017, near the entire region of the Tamil Nadu shoreline of India, the collision of two merchant vessels caused the spill of hazardous oil and liquid petroleum gas (LPG). This oil spill, accounting for a quantity of about 1.1 metric tonnes, has caused severe damage to the ecosystem, marine life, and presents health hazards to the residents living in the vicinity of the seashore. Moreover, with the operation of more than 700 wells for the extraction of oil and gas in the state of Tamil Nadu and along with 31 additional contract areas awarded as a part of discovered small fields (DSF) by the Cabinet Committee of Economic Affairs (CCEA), the possible soil hydrocarbon contamination and bioremediation of such affected areas is receiving considerable attention in the state of Tamil Nadu in India today.

The aims of the present study were: (1) to isolate and characterize rhamnolipid-producing bacterial strains from various hydrocarbon-contaminated soils in Tamil Nadu, India; (2) to optimize the rhamnolipid production of the obtained bacterial strains; (3) to assess the efficiency of the application of rhamnolipid-producing strains and produced rhamnolipids singly and in different combinations in the bioremediation of oil-polluted soil.

\section{Materials and Methods}

\subsection{Rhamnolipid-Producing Bacterial Strain Isolation and Screening}

\subsubsection{Soil Sampling and Strain Isolation}

To obtain bacterial strains capable of rhamnolipid production, the soil was collected from hydrocarbon-contaminated areas of gasoline refueling stations and automobile service stations located 
in Tamil Nadu, India. Bacteria from one gram of soil from contaminated site was enriched using an M9 minimal salt medium comprising sodium phosphate (dibasic) hepahydrate- $25.6 \mathrm{gL}-{ }^{1}$, monopotassium phosphate- $6 \mathrm{gL}^{-1}$, sodium chloride- $1 \mathrm{gL}^{-1}$, ammonium chloride- $2 \mathrm{gL}^{-1}$ supplemented with $2 \%$ crude oil. The contents were maintained in an orbital shaker at $200 \mathrm{rpm}$ for 7 days. The cultures were isolated using the same M9 minimal salt medium supplemented with $1.5 \%$ agar. Plates were incubated at $30^{\circ} \mathrm{C}$ for $120 \mathrm{~h}$, and the isolates that showed positive growth were subjected to PCR-based screening for the presence of the RhlAB operon.

\subsubsection{Screening for the Presence of the RhlAB operon}

The 842-bp fragment of the RhlAB operon covering regions of both RhlA and RhlB genes was amplified using the primers RhlABf (50-CAGGCCGATGAAGGGAAATA-30 and RhlABr (50-AGGACGA CGAGGTGGAAATC-30), as described by Ochsner et al. [10]. The reactions were carried out in a $25-\mu \mathrm{L}$ volume of a reaction mixture $\left(25 \mathrm{mM} \mathrm{MgCl}_{2}, 10 \times\right.$ PCR buffer, $10 \mathrm{mM}$ dNTP, $5 \mathrm{U} / \mu \mathrm{L}$ Taq, $0.2 \mu \mathrm{M}$ each primer, and $0.1 \mu \mathrm{g}$ of template genomic DNA). The PCR conditions were as follows: initial denaturation at $95^{\circ} \mathrm{C}$ for $5 \mathrm{~min}$, followed by 30 cycles of $30 \mathrm{~s}$ of denaturation at $95^{\circ} \mathrm{C}$, then $1 \mathrm{~min}$ of primer annealing at $50^{\circ} \mathrm{C}$ and $2 \mathrm{~min}$ of extension at $72{ }^{\circ} \mathrm{C}$, and a final extension step at $72{ }^{\circ} \mathrm{C}$ for $10 \mathrm{~min}$. Separation of PCR products was carried out using agarose gel electrophoresis, and the product testing was performed at $305 \mathrm{~nm}$ using a Gel Documentation System (Alpha Imager HP, Protein Simple, San Jose, CA, USA).

\subsubsection{Screening of the Bacterial Strains for Biosurfactants Production Ability}

A qualitative drop-collapse test was applied for the screening of selected strains for biosurfactant production ability using the method proposed by Bodour and Miller-Maier [19]. The result was considered positive for biosurfactant production when the drop was flat and negative when cultures produced rounded drops [20].

An oil-spreading assay was carried out, as described by Morikawa et al. [21]. In brief, $10 \mu \mathrm{L}$ of oil was added to the surface of $40 \mathrm{~mL}$ distilled water to form a thin oil layer. A total of $10 \mu \mathrm{L}$ of culture supernatant was gently placed on the center of the oil layer. Clearing zone due to the displacement of oil by the supernatant indicated the positive presence of biosurfactant.

An emulsification index, which measures the emulsification ability of the biosurfactant in the culture broth, was measured according to the method described by Cooper and Goldenberg [22]. Briefly, the assay was carried out in a test tube by adding kerosene to the cell-free culture broth at a ratio of 1:1, followed by which the tubes were vortexed vigorously for two minutes. The mixtures were allowed to settle for $24 \mathrm{~h}$ before the percentage of the volume occupied by the emulsion was determined. The equation used to determine the emulsion index $\left(\mathrm{EI}_{24}\right)$ was as follows:

$$
\mathrm{EI}_{24}(\%)=\frac{\text { The height of the emulsion layer }}{\text { The height of the total solution }} \times 100
$$

The surface tension of the liquid was measured with a Traube Stalagmometer, as described by Plaza et al. [23]. The surface tension $\left(\mathrm{mN} \mathrm{m}^{-1}\right)$ was calculated using the following formula:

$$
\sigma_{L}=\frac{\sigma w * N w * \rho L}{N L * \rho w}
$$

where $\sigma_{L}$ is the surface tension of the liquid under investigation, $\sigma_{W}$ is the surface tension of water, $N_{L}$ is the number of drops of the liquid, $N_{W}$ is the number of drops of water, $\rho_{L}$ is the density of the liquid, $\rho_{W}$ is the density of water. 


\subsubsection{Selected Bacterial Strain Identification}

For identification of the biosurfactant-producing bacteria, the $16 \mathrm{~S}$ rRNA gene was amplified using the universal primers 8f (5'-AGAGTTTGATCCTGGCTCAG-3') and 1489r (5'-TACCTTGTTACGACTTCA-3'), as described by Eden et al. [24], with the conditions described below. The reaction was carried out in $25-\mu \mathrm{L}$ volume containing $25 \mathrm{mM} \mathrm{MgCl}_{2}, 10 \times \mathrm{PCR}$ buffer, 10 $\mathrm{mM}$ dNTP, $5 \mathrm{U} / \mu \mathrm{L}$ Taq, $0.2 \mu \mathrm{M}$ of each primer, and $0.1 \mu \mathrm{g}$ of template genomic DNA. The following PCR conditions were applied: initial denaturation at $94{ }^{\circ} \mathrm{C}$ for $3 \mathrm{~min}$, followed by 25 cycles of denaturation at $94{ }^{\circ} \mathrm{C}$ for $45 \mathrm{~s}$, annealing at $55^{\circ} \mathrm{C}$ for $45 \mathrm{~s}$, and extension at $70{ }^{\circ} \mathrm{C}$ for $2 \mathrm{~min}$, with a final extension at $72{ }^{\circ} \mathrm{C}$ for $7 \mathrm{~min}$. The reaction was conducted using Palm cycler ${ }^{\mathrm{TM}}$ (Corbet Life Science, Sydney, Australia). The PCR products were purified using a Hipure ${ }^{\mathrm{TM}}$ gel purification kit (Himedia, Mumbai, India) and were loaded on 2\% agarose gel. The obtained $16 \mathrm{~S}$ rDNA gene sequence was identified based on the Ribosomal Database Project (RDP) classifier [25] and phylogenetic tree construction was performed using the software MEGA 5.2, using the neighbor-joining (NJ) method with 1000 bootstrap replications, as described by Tamura et al. [26]. The 16S rRNA gene nucleotide sequence was deposited in NCBI under accession number KT763389.

\subsection{Rhamnolipid Production of the Isolate Under Laboratory Conditions}

\subsubsection{Optimization of Rhamnolipid Production}

A central composite design (CCD) was applied to optimize the rhamnolipid production of the selected bacterial strain (Box and Wilson, 1951). The experiment was carried out in 500-mL Erlenmeyer flasks containing $200 \mathrm{~mL}$ of mineral salt medium (MSM), amended with crude oil as a sole carbon source. Thirty treatments factors (runs) with variable substrate concentrations, $\mathrm{pH}$, temperature, and inoculation loads were the factors used in the experiment (Table S1). The coded values were- $\alpha,-1,0,1,+, \alpha$, with the corresponding values of parameters: for A (crude oil concentration) $0,1,2,3$, and $4 \%$; B (inoculation load) $35 \times 10^{2}, 10 \times 10^{4}, 29 \times 10^{5}, 16 \times 10^{7}$, and $33 \times 10^{8} \mathrm{CFU} \mathrm{mL}^{-1}$; $\mathrm{C}(\mathrm{pH}) 3.5,5.0,6.5,8.0$, and 9.5; $\mathrm{D}$ (temperature) $12.5,20.0,27.5,35$, and $42.5^{\circ} \mathrm{C}$. The agitation was maintained at $150 \mathrm{rpm}, 120 \mathrm{~h}$, during the experiment. Rhamnolipid production was quantified as rhamnose equivalents (RE) using the phenol-sulfuric acid method with a standard curve prepared using rhamnose [27]. The critical micelle concentration (CMC) of the biosurfactant was determined based on a plot of surface tension vs. surfactant concentration (expressed $\mathrm{mg} \mathrm{mL}^{-1}$ ) [28].

The results of the experiments were analyzed using Design-Expert 9.0 software (Stat-Ease, Inc., Minneapolis, MN, USA), and the following second-order polynomial regression model equation was obtained:

$$
\begin{gathered}
Y=\beta_{0}+\beta_{1} A+\beta_{2} B+\beta_{3} C+\beta_{4} D+\beta_{11} A+\beta_{22} B^{2}+\beta_{33} C^{2+} \beta_{44} D^{2+} \beta_{12} A B+\beta_{13} A C \\
+\beta_{14} A D+\beta_{23} B C+\beta_{24} B D+\beta_{34} C D
\end{gathered}
$$

where $\mathrm{Y}$ represents the predicted response (rhamnolipid production in $\mathrm{RE}$ ), $\mathrm{b} 0$ is an intercept, $\mathrm{A}$ is the crude oil concentration (\%), $\mathrm{B}$ is the inoculation load $\left(\mathrm{CFU} \mathrm{mL}{ }^{-1}\right), \mathrm{C}$ is $\mathrm{pH}$, and $\mathrm{D}$ is the temperature $\left({ }^{\circ} \mathrm{C}\right) . \beta 1, \beta 2, \beta 3$, and $\beta 4$ are the linear coefficients; $\beta 11, \beta 22, \beta 33$, and $\beta 44$ are the squared coefficients; $\beta 12, \beta 13, \beta 14, \beta 23, \beta 24, \beta 34$ are the interaction coefficients; $A^{2}, B^{2}, C^{2}, D^{2}$, and $A B, A C, A D, B C, B D$, $\mathrm{CD}$ represent the interactions between factors $\mathrm{A}, \mathrm{B}, \mathrm{C}$, and $\mathrm{D}$.

\subsubsection{Extraction, Partial Purification, and Characterization of Rhamnolipids}

Crude biosurfactant extraction was carried out, as described by Yakimov et al. [29] Briefly, centrifugation $(15 \mathrm{~min}$ at $10,000 \times \mathrm{g}$ ) was applied to obtain a cell-free supernatant from bacterial cultures grown for $24 \mathrm{~h}$. Cultures with more than $40 \times 10^{6} \mathrm{CFU} \mathrm{mL}{ }^{-1}$ were used. $\mathrm{HCl}$ was added to the supernatant to reduce the $\mathrm{pH}$ to 2 , and then the suspension was kept at $4{ }^{\circ} \mathrm{C}$ for $24 \mathrm{~h}$. The biosurfactant 
was extracted with chloroform-methanol $(3: 1, \mathrm{v}: \mathrm{v})$. Finally, the precipitate was decanted, and the solvent was evaporated.

Thin-layer chromatography (TLC) was used for the identification of the biosurfactants, according to the protocols of Smyth et al. [30]. Silica gel plates were prepared by adding $30 \mathrm{~g}$ of silica-G (200-245 mesh) to $60 \mathrm{~mL}$ distilled water followed by mixing. Microscopic slides were coated by the slurry and air-dried. Ten microliters of the purified biosurfactant fraction were applied at the point of origin (near the bottom) of each preparative silica gel plate. The silica gel plates containing biosurfactant were eluted using a solution mix of chloroform-methanol-acetic acid (65:15:2, v/v/v) and visualized using iodine vapors.

The retention factor $\left(R_{f}\right)$ value of BS was calculated according to the following formula:

$$
R_{f}=\frac{\text { Distance travelled by the substance }}{\text { Distance travelled by the solvent }}
$$

For partial rhamnolipid purification, rhamnolipids specifying TLC spots were dissolved in $1 \mathrm{~mL}$ methanol and centrifuged at $15,000 \times g$ for $3 \mathrm{~min}$ at $4{ }^{\circ} \mathrm{C}$ to remove the silica gel. The supernatant was collected, air-dried for $24 \mathrm{~h}$, followed by dissolving the dried fraction in $25 \mu \mathrm{L}$ methanol. Finally, the rhamnolipids were separated by centrifugation at $1000 \times g$ for $10 \mathrm{~min}$ and air-drying. The dried fraction was further purified on a silica gel (60-120 mesh) column eluted with a gradient of chloroform and methanol, as described by Sharma et al. [31].

Fourier transform infrared spectroscopy (FT-IR) was used for the characterization of extracted rhamnolipids. The IR spectra of TLC-purified rhamnolipids were recorded using an FT-IR spectrometer (AVATAR 330 FFT-IR system, Thermo Electron Corporation, Madison, WI, USA) in the $4000-400 \mathrm{~cm}^{-1}$ spectral region using potassium bromide solid cells. The spectra were recorded for the different pellets and analyzed using the standard methods described previously by Yin et al. [32].

\subsection{Soil Bioremediation Study}

\subsubsection{Experimental Design}

A 120-day experiment evaluating rhamnolipid suitability for enhanced oil recovery was carried out with artificially contaminated soil (supplemented with $10 \%$ of crude oil), as described by Silva et al. [33]. The soil (normal soil) used in the bioremediation experiment was sandy clay loam soil with a bulk density of $129.6 \mathrm{~g} \mathrm{~cm}^{3}$, a pH of 7.4, and an electric conductivity of $0.21 \mathrm{dsm}^{-1}$, and contained $74.2 \mathrm{mg} \mathrm{kg}^{-1}$ of available $\mathrm{N}, 149.6 \mathrm{mg} \mathrm{kg}^{-1}$ of available $\mathrm{K}, 6.4 \mathrm{mg} \mathrm{kg}^{-1}$ of available $\mathrm{P}$, and $0.32 \%$ of organic matter. The microbial biomass- $\mathrm{C}$ was $321 \mu \mathrm{g} \mathrm{g}$, total bacterial abundance was $24 \times 10^{5}$ CFU g ${ }^{-1}$, fungal abundance was $40 \times 10^{3} \mathrm{CFU} \mathrm{g}^{-1}$, and autochthonous hydrocarbon-degrading bacterial abundance was $30 \times 10^{2} \mathrm{CFU} \mathrm{g}^{-1}$ in the normal soil. The following treatments were included in the experiment: (1) contaminated soil (CS); (2) contaminated soil + normal soil (1:1) (CS+NS); (3) rhamnolipid-treated contaminated soil + normal soil (TS+NS) (1:1 ratio); (4) contaminated soil + normal soil + rhamnolipid-producing bacteria (Shewanella sp. BS4) (CS + NS + RPB); (5) contaminated soil + rhamnolipid-producing bacteria (CS+RPB); (6) rhamnolipid-treated contaminated soil + rhamnolipid-producing bacteria (TS + RPB); (7) rhamnolipid-treated contaminated soil + normal soil + rhamnolipid-producing bacteria (TS + NS + RPB). The rhamnolipid-treated soil (TS) was obtained by mixing CS and biosurfactant at a concentration of $2 \%(\mathrm{v} / \mathrm{w})$. The bacterial treatment was established by adding Shewanella sp., $24 \times 10^{8} \mathrm{CFU} \mathrm{g}^{-1}$ at $1 \% \mathrm{v} / \mathrm{w}$ (volume/weight). In all treatments, the soil moisture content was maintained at $50 \%$ during the whole experiment. The soil used for the CS and TS treatments was sterilized before the bioremediation experiment.

\subsubsection{Estimation of Bacterial Abundance and Activity in Treated Soils}

The abundance of hydrocarbon-degrading bacteria was estimated in MSM using $0.1 \%$ diesel as a carbon source based on the protocol of Benincasa [34]. The plates were maintained at $28 \pm 2{ }^{\circ} \mathrm{C}$ for 21 
days. Soil basal respiration (SR) was measured according to the method proposed by Bekku et al. [35]. Briefly, in a $250 \mathrm{~mL}$ conical flask, $20 \mathrm{~g}$ of moist soil was adjusted to a $60 \%$ water-holding capacity and amended with $0.2 \mathrm{~N} \mathrm{NaOH}$ in a $10 \mathrm{~mL}$ tube placed inside the flask to trap the $\mathrm{CO}_{2}$ resulting from mineralization. Ten milliliters of $\mathrm{BaCl}_{2}$ was added to the $\mathrm{NaOH}$ trap and incubated in the dark for seven days. The amount of $\mathrm{CO}_{2}$ production was then measured using titration with $0.1 \mathrm{~N} \mathrm{HCl}$, and the respiration rate was calculated (expressed as $\mathrm{mg}$ of $\mathrm{CO}_{2} \mathrm{~g}^{-1}$ of soil $\mathrm{h}^{-1}$ ).

Dehydrogenase (DHA) activity in the differently treated soils was determined using 2,3,5-triphenyltetrazoliumchloride (TTC) as a substrate, according to Pepper et al. [36]. The samples were incubated for $24 \mathrm{~h}$ at $37^{\circ} \mathrm{C}$, the formation of 1,3,5-triphenyl formazan (TPF) was determined photometrically at $485 \mathrm{~nm}$, and the results are expressed as $\mathrm{mg} \mathrm{TPF} \mathrm{g}^{-1}$ of soil $\mathrm{h}^{-1}$.

\subsubsection{Estimation of the Total Petroleum Hydrocarbon Content in Soil}

The total petroleum hydrocarbon (TPH) content in contaminated soils was estimated gravimetrically, as described by Peng et al. [37]. Briefly, $25 \mathrm{~mL}$ of dichloromethane was added to five grams of petroleum-contaminated soil in a centrifuge tube, and the contents were centrifuged at $10,000 \times g$ for $5 \mathrm{~min}$. The supernatant was then transferred to an Erlenmeyer flask for the evaporation of dichloromethane at $65{ }^{\circ} \mathrm{C}$, and the amount of residual TPH was determined gravimetrically.

\subsubsection{Germination Assay}

To test the toxic effect of differently treated soils on plants, a germination assay was carried out according to the methods of Marecik and Biegańska-Marecik [38]. Briefly, $40 \mathrm{~g}$ of soil from each treatment was placed into a Petri dish $(150 \mathrm{~mm})$ containing sterile soil with a $65 \%$ water holding capacity (adjusted with distilled water). Twenty red pepper seeds were gently pressed into the soil and incubated in covered Petri dishes at $25^{\circ} \mathrm{C}$ under dark conditions for $72 \mathrm{~h}$. The number of germinated seeds was recorded at periodic intervals of $0,3,6,9,12,24$ days, and the germination percentage was calculated.

\subsection{Statistical Analysis}

A minimum of six replications was maintained for each experiment unless mentioned specifically. Data were subjected to one-way ANOVA (analysis of variance) and tested for significance at a $p$-value of 0.05 . For the bioremediation experiment, the experimental design adopted was RBD (randomized block design).

\section{Results and Discussion}

\subsection{The Characteristics of Isolated Rhamnolipid-Producing Bacterial Strain}

\subsubsection{Genetic Characterization of the Strains}

In the present study, we isolated rhamnolipid-producing bacterial strains from soils from different hydrocarbon-contaminated sites. Among a total of 37 morphologically and biochemically distinct isolates that were able to grow on a mineral salt medium supplemented with $2 \%$ crude oil, the presence of the RhlAB operon was confirmed for four isolates by PCR analysis (Figure S1). Among these four strains, one isolate-labeled BS4 was selected for further study based on its higher biosurfactant production ability. This isolate exhibited a positive reaction to the drop collapse test and had maximum oil displacement $-7 \mathrm{~mm}$ in diameter. This strain showed a surface tension value of $20.8 \mathrm{mN} \mathrm{m}^{-1}$ in MSM and yielded $\mathrm{EI}_{24}(\%)$ values of $62.4 \%$ and $11.4 \%$ with respect to cell and cell-free extracts, respectively. In comparison, Pseudomonas aeruginosa strain MTCC 2453 provided a surface tension value of $26.7 \mathrm{mN} \mathrm{m}^{-1}$ and EI of $62.7 \%$. The strain BS4 was identified as Shewanella sp. based on $16 \mathrm{~S}$ rRNA gene analysis. A comparative phylogenetic analysis of this strain with other members of the Shewanella genus is provided in Figure 1. 


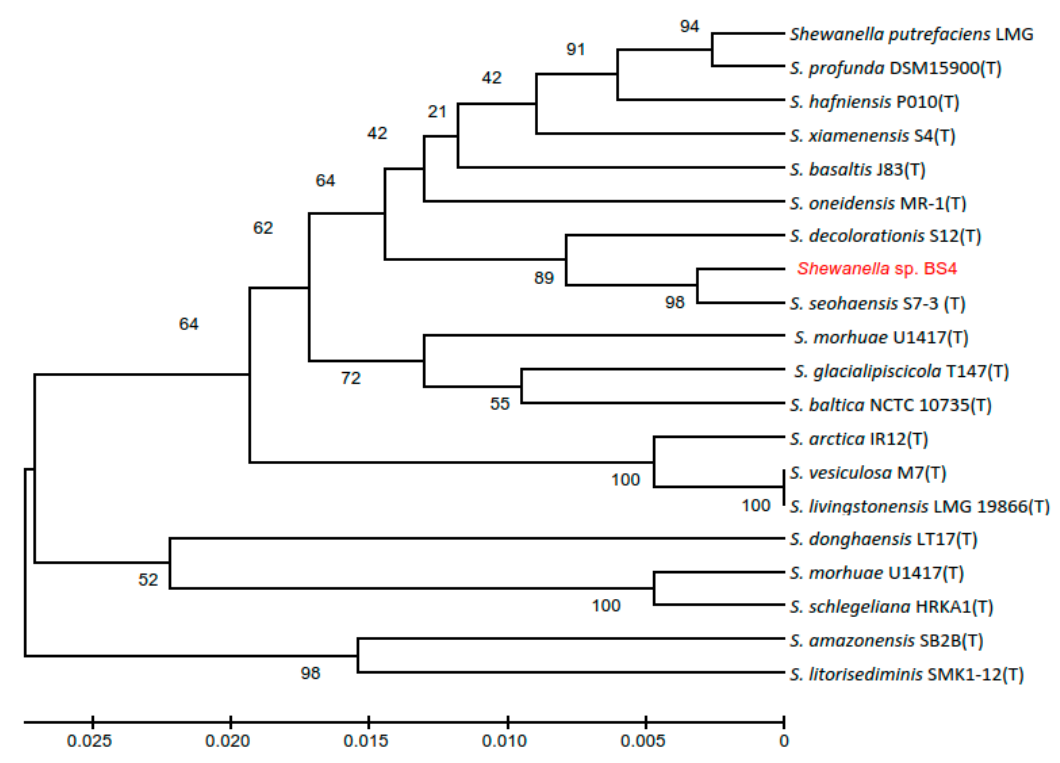

Figure 1. Phylogenetic tree showing the position of Shewanella sp. BS4 and its closest neighbors with a bootstrap value of 1000 .

The frequent occurrence of Shewanella spp. in hydrocarbon-contaminated sites and their role in bioremediation has been reported in the literature [39-41]. For example, Shewanella putrefaciens was isolated from the Prestige oil spill in Spain [42], and Shewanella alga and Shewanella upenei, among predominant biosurfactants-producing bacteria, were isolated from the crude oil-contaminated sediments and seawater samples collected from five stations in the Persian Gulf [43]. Much has been studied with respect to the RhlAB operon that harbors both RhlA and RhlB enzymes that are responsible for mono-rhamnolipid biosynthesis in P. aeruginosa [10,11,44,45]. The presence of the RhlAB operon in Serratia rubidaea strain SNAU02, responsible for rhamnolipid synthesis, was confirmed by Nalini and Parthasarthy [17].

\subsubsection{Production of Biosurfactant by the Isolate under Optimized Conditions}

In the present study, four parameters, namely, oil concentration, inoculation load, temperature, and $\mathrm{pH}$, were evaluated for their influence on rhamnolipid production by the isolated bacterial strain. Second-order polynomial equation fitted using multiple regression analysis was applied for the optimization of rhamnolipid production. A second-order response model obtained after regression analysis for rhamnolipid production was described by the following equation:

$$
\begin{gathered}
\mathrm{R} 1=+2.02+0.52 \times \mathrm{A}+0.24 * \mathrm{~B}+0.054 * \mathrm{C}+0.021 * \mathrm{D}-0.17 * \mathrm{AB}+0.019 * \mathrm{AC}+0.019 * \mathrm{AD} \\
-0.031 * \mathrm{BC}-6.25 * \mathrm{BD}+0.031 * \mathrm{CD}-0.18 * \mathrm{~A}^{2}-0.028^{*} \mathrm{~B}^{2}-0.12 * \mathrm{C}^{2}-0.12 * \mathrm{D}^{2}
\end{gathered}
$$

where $\mathrm{A}$ is the oil concentration, $\mathrm{B}$ the inoculation load, $\mathrm{C}$ the temperature, and $\mathrm{D}$ the soil $\mathrm{pH}$. The parameters of the experimental Central Composite Design (CCD) runs, and the corresponding results are provided in Supplementary Table S1.

The predicted $R^{2}$ value $(0.827)$ was in reasonable agreement with the adjusted $R^{2}$ value $(0.935)$ since the difference was less than 0.2 (Table 1). Based on the results obtained from the experiment designed according to the CCD model, the optimum concentration of crude oil was $2.9 \%$, the inoculation load was $54 \times 10^{6} \mathrm{CFU} \mathrm{mL}{ }^{-1}$, the temperature was $30.5^{\circ} \mathrm{C}$, and the $\mathrm{pH}$ value was 6.7 . The results of the experiment showed that an increase in crude oil concentration and inoculation load increased rhamnolipid production at a fixed $\mathrm{pH}$ and temperature $\left(6.5\right.$ and $27.5{ }^{\circ} \mathrm{C}$, Figure $\left.2 \mathrm{a}\right)$. The predicted and experimental values for rhamnolipid production were close to a straight line (Figure 2b). 
Table 1. Results of ANOVA for the response surface quadratic model.

\begin{tabular}{cccccc}
\hline Source & Sum of Squares & Degrees of Freedom & Mean Square & $f$ Value & $p$-Value \\
\hline Model & 9.73 & 14 & 0.69 & 30.73 & $<0.0001$ \\
A-Crude oil & 6.51 & 1 & 6.51 & 287.93 & $<0.0001$ \\
B-Inoculation load & 1.35 & 1 & 1.35 & 59.87 & $<0.0001$ \\
C-Temperature & 0.07 & 1 & 0.07 & 3.11 & 0.0980 \\
D-pH & 0.01 & 1 & 0.01 & 0.46 & 0.5076 \\
AB & 0.46 & 1 & 0.46 & 20.15 & 0.0004 \\
AC & 5.62 & 1 & 5.62 & 0.25 & 0.6252 \\
AD & 5.62 & 1 & 5.62 & 0.25 & 0.6252 \\
BC & 0.01 & 1 & 0.01 & 0.69 & 0.4189 \\
BD & 1 & 6.25 & 0.02 & 0.8702 \\
CD & 1.25 & 1 & 0.01 & 0.69 & 0.4189 \\
A`2 & 0.01 & 1 & 0.87 & 38.49 & $<0.0001$ \\
B`2 & 0.87 & 1 & 0.02 & 0.96 & 0.3428 \\
C`2 & 0.02 & 1 & 0.37 & 16.22 & 0.0011 \\
D`2 & 0.37 & 1 & 0.37 & 16.22 & 0.0011 \\
Residual & 0.37 & 15 & 0.02 & & \\
Lack of Fit & 0.34 & 10 & 0.02 & 3.01 & 0.1179 \\
Pure Error & 0.29 & 5 & 9.66 & & \\
Cor Total & 0.04 & 29 & & & \\
\hline
\end{tabular}

When bacterial growth and rhamnolipid production were studied in CCD-optimized growth medium, the highest bacterial abundance, $58 \times 10^{6} \mathrm{CFU} \mathrm{mL}^{-1}$, was attained after $96 \mathrm{~h}$ of incubation, and the rhamnolipid production was observed to be $2.5 \mathrm{mg}$ cell dry weight (CDW) (Figure 2c). The CMC value of the biosurfactant was 27.4 (Figure 2d).

Several studies have utilized CCD for the successful optimization of rhamnolipid production in the case of P. aeruginosa strains, such as AT10 [46], ATCC9027 [46], and P. aeruginosa SG [47], but no study on rhamnolipid production using Shewanella species has been carried out previously. We adopted the response surface methodology for maximization of rhamnolipid production using the optimization of operational factors [48]. Sharon [49] reported that Shewanella putrefaciens strain LH4:18 could grow on crude oil under anaerobic conditions without the addition of any other carbon source. However, Shewanella species are shown to be facultative aerobes using either oxygen under aerobic conditions or oxidized metals under anaerobic conditions as the terminal electron acceptor [50].

\subsubsection{The Characteristics of Rhamnolipids Produced by the Isolate}

TLC analysis revealed the presence of mono- and di-rhamnolipids based on the spots at $R f$ values of 0.31 and 0.81 in the biosurfactant mixture produced by the isolated Shewanella strain (Figure 3a). These results are per the findings of Nalini and Parthasarathi [17], who observed characteristic bands of the di- and mono- rhamnolipid-type biosurfactants at $R f$ values of 0.38 and 0.85 , respectively. FTIR analysis also confirmed the presence of a rhamnolipid-type biosurfactant based on the peaks located at 2929, 1636, 1405, 1222, and $1061 \mathrm{~cm}^{-1}$, which corresponded to the presence of $\mathrm{CH}$ stretching vibration, $\mathrm{C}=\mathrm{O}$ stretching vibration, $\mathrm{CH} / \mathrm{OH}$ deformation, $\mathrm{CH}$ deformation, and $\mathrm{C}-\mathrm{O}$ stretching, respectively (Figure 3b). Leitermann et al. [51] showed that double bands at 2921 and $2855 \mathrm{~cm}^{-1}$ corresponded to $\mathrm{C}-\mathrm{H}$ vibrations, which represent the hydroxydecanoic acid chain tails of rhamnolipid, while the $\mathrm{C}=\mathrm{O}$ stretching band at $1730 \mathrm{~cm}^{-1}$ is due to the presence of esters and carboxylic acid groups. The area between 1200 and $1460 \mathrm{~cm}^{-1}$ represents $\mathrm{C}-\mathrm{H}$ and $\mathrm{O}-\mathrm{H}$ deformation vibrations, which are characteristic features of carbohydrate molecules. The other peaks might have occurred due to the protein contamination that occurred during the extraction process. 


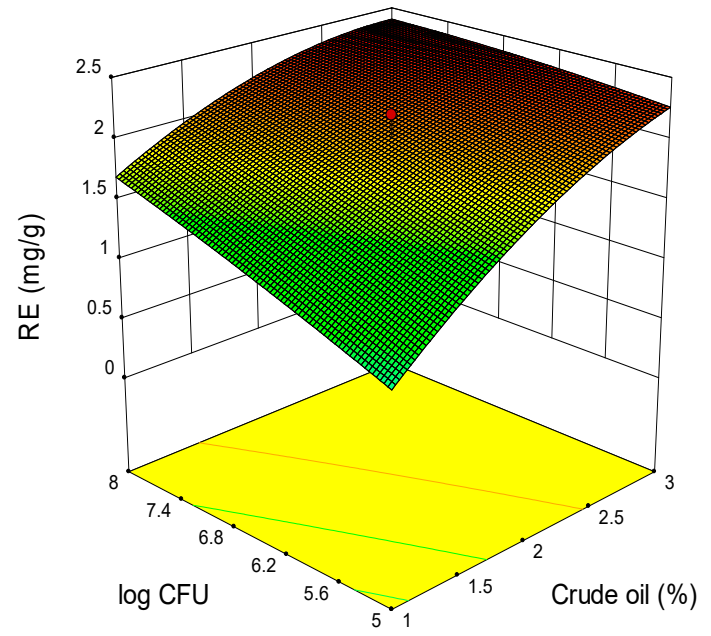

(a)

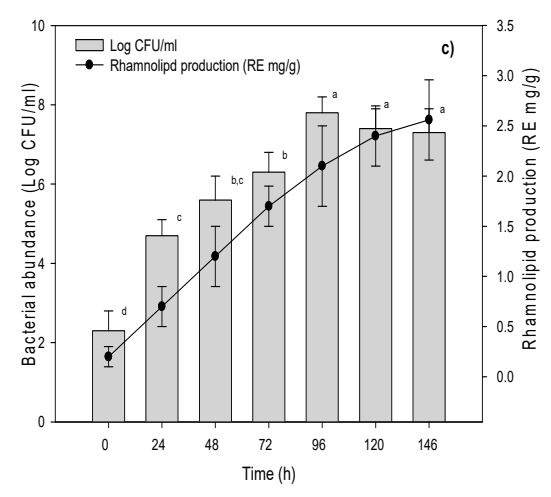

(c)
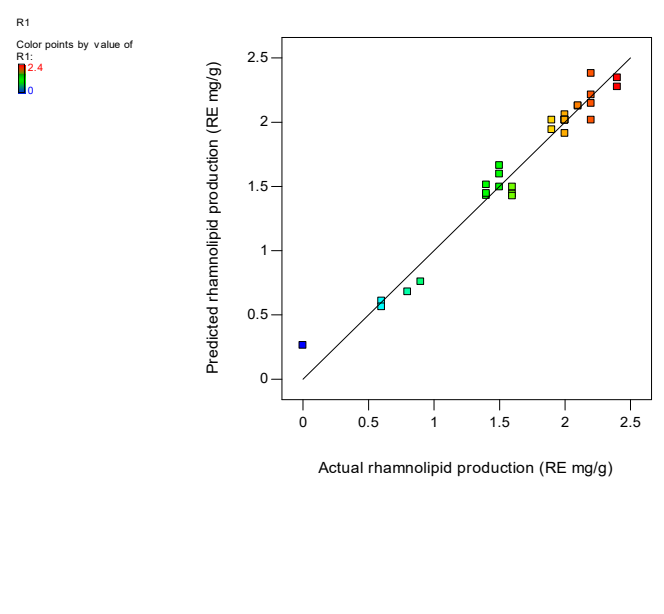

(b)

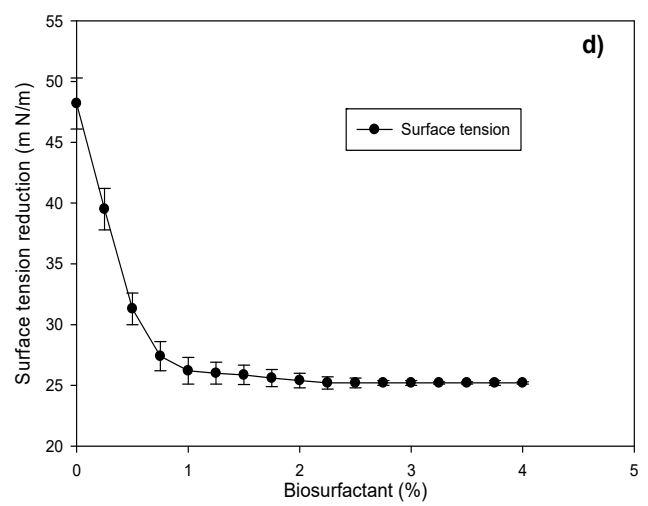

(d)

Figure 2. (a) Three-dimensional contour plot for maximum rhamnolipid production expressed as RE (rhamnose equivalents) $\mathrm{mg} \mathrm{g}^{-1}$ cell dry weight as a function of inoculation load and crude oil (\%), (b) Predicted vs. actual values for rhamnolipid production based on response surface methology (c) Growth and rhamnolipid production in RSM optimized media, (d) Graph of surface tension vs. concentration of the rhamnolipid. Different lower case letters after values indicate a significant difference at a $p$-value of 0.05 as determined by Duncan's multiple range test.

\subsection{Treatment Efficiency of the Contaminated Soil Under Different Bioremediation Conditions}

The bioremediation experiment revealed significant differences in the removal efficiencies of hydrocarbons between all treatments. The highest hydrocarbon removal efficiency of $75.8 \%$ was observed in the TS + NS + RPB treatment (Figure 4a). Soil respiration $\left(0.6 \mathrm{mg} \mathrm{CO}_{2} \mathrm{~g}^{-1} \mathrm{~h}^{-1}\right)$ (Figure $4 \mathrm{~b}$ ), DHA activity $\left(5.2 \mu \mathrm{g} \mathrm{TPF} \mathrm{g}{ }^{-1}\right.$ soil $\left.24 \mathrm{~h}^{-1}\right)$ (Figure $4 \mathrm{c}$ ), and the highest hydrocarbon-degrading bacterial abundance $\left(42 \times 10^{6} \mathrm{CFU} \mathrm{g}^{-1}\right)$ (Figure $4 \mathrm{~d}$ ) were obtained in the TS + NS + RPB treatment by the 90th day of the experiment, and this activity was $44.4 \%, 80.6 \%$, and $39.5 \%$ higher, respectively, than that in the CS alone treatment. At the end of the experiment on day 135, there were no significant increases in hydrocarbon-degrading bacterial population and DHA activity, and a decrease of $17.5 \%$ in soil respiration activity was observed. 

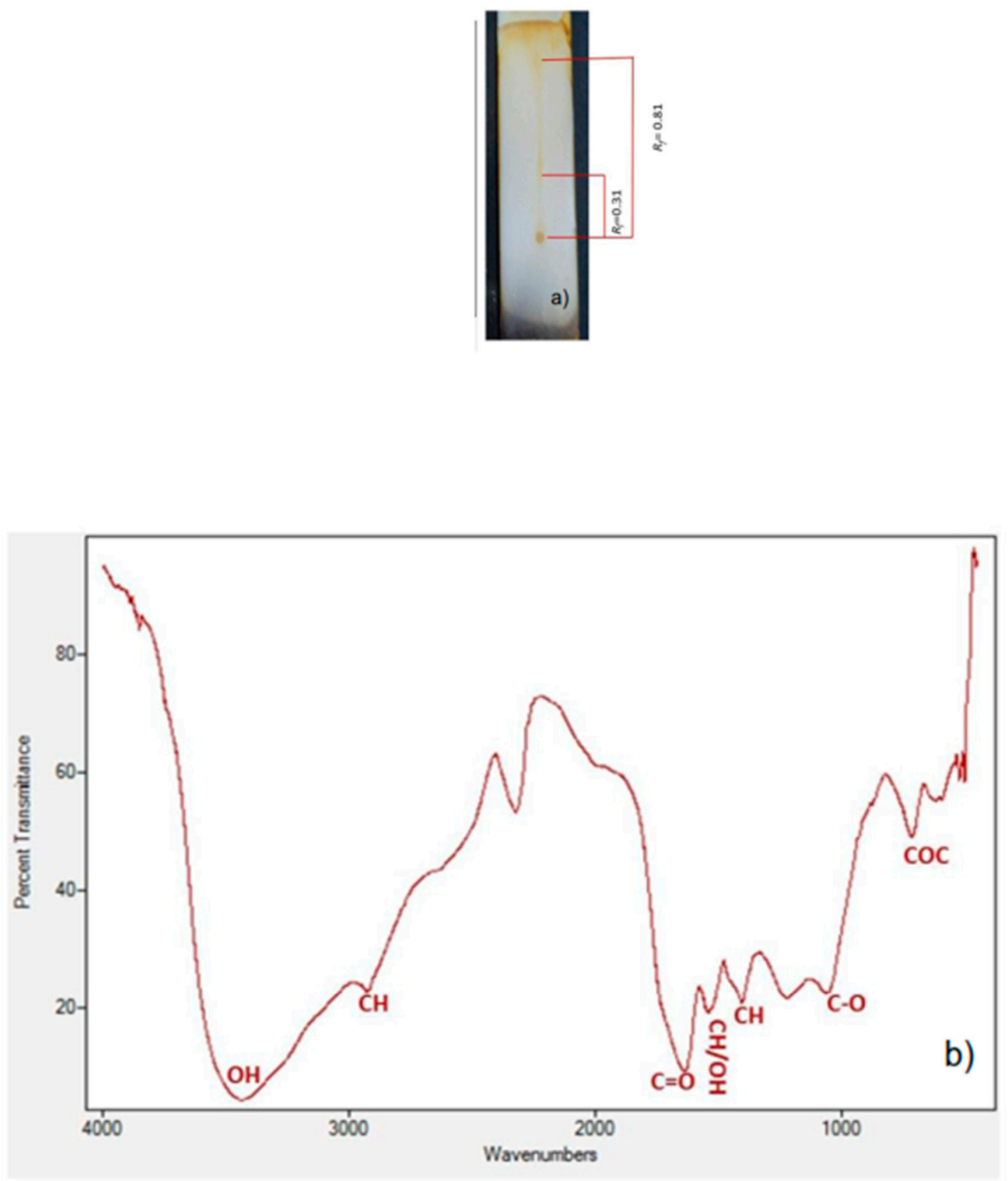

Figure 3. The thin-layer chromatographic slide proving mono- and di-rhamnolipid presence in the extracted mixture (a) and Fourier transform infrared spectroscopic (FT-IR) spectra confirming the presence of a rhamnolipid-type biosurfactant $(\mathbf{b}) . R f$-retention factor $(0.31$ for di-rhamnolipid and 0.81 for mono-rhamnolipid). 


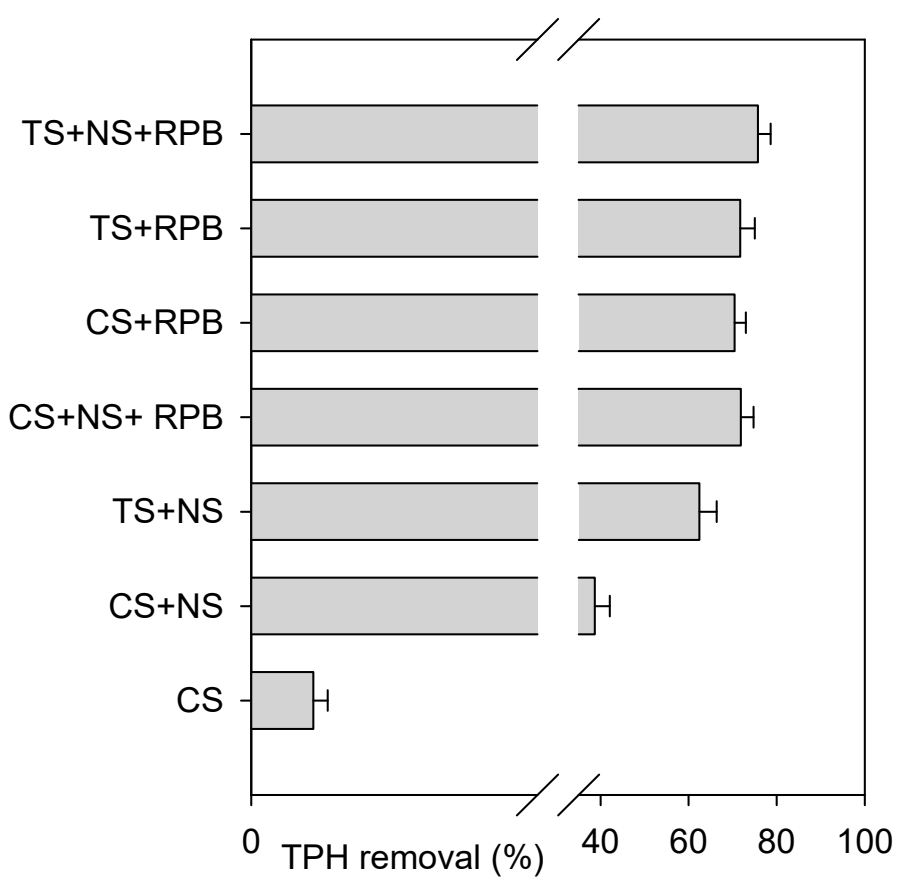

(a)

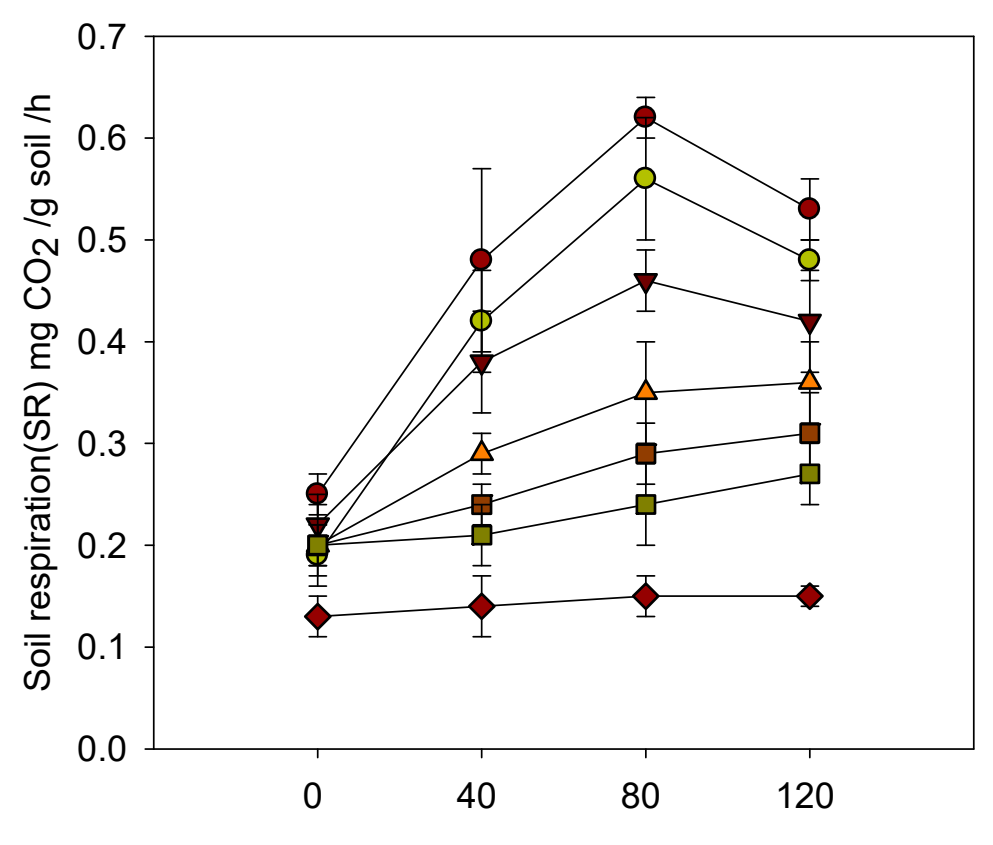

(b)

Figure 4. Cont. 


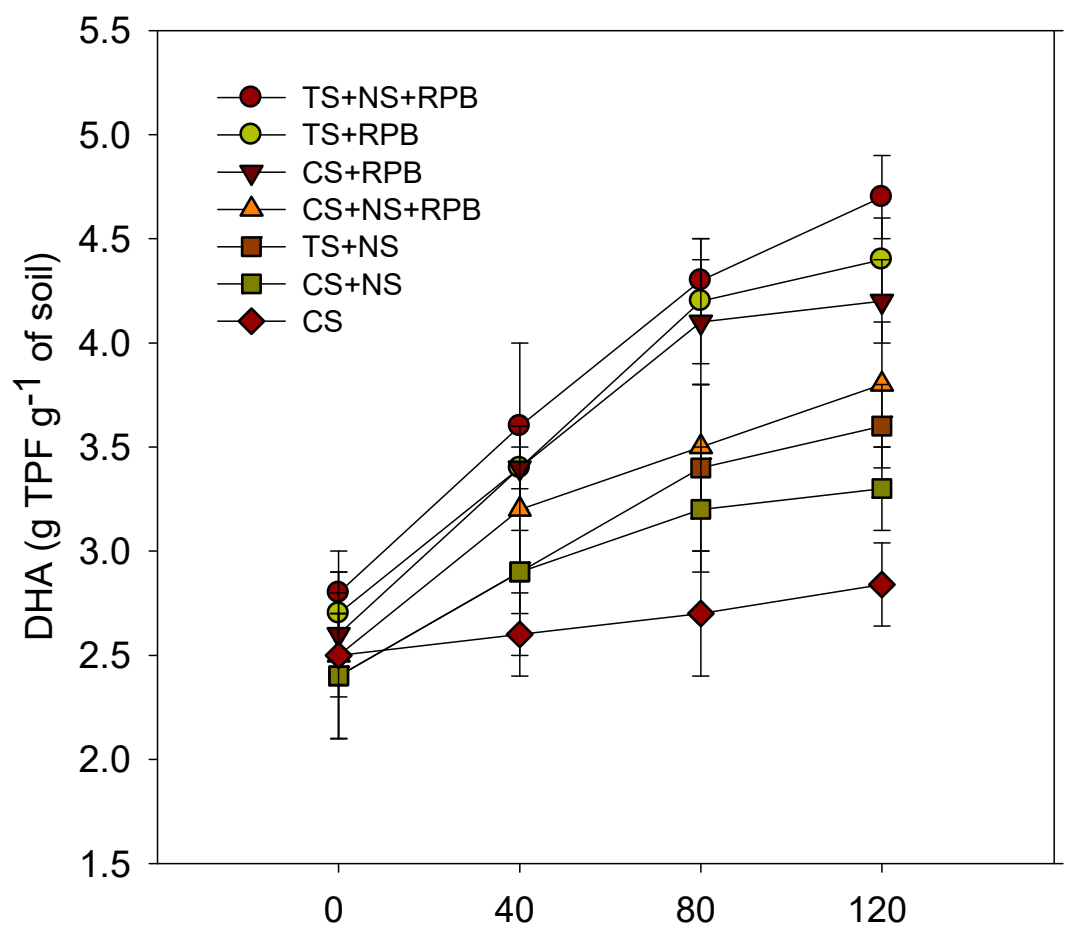

(c)

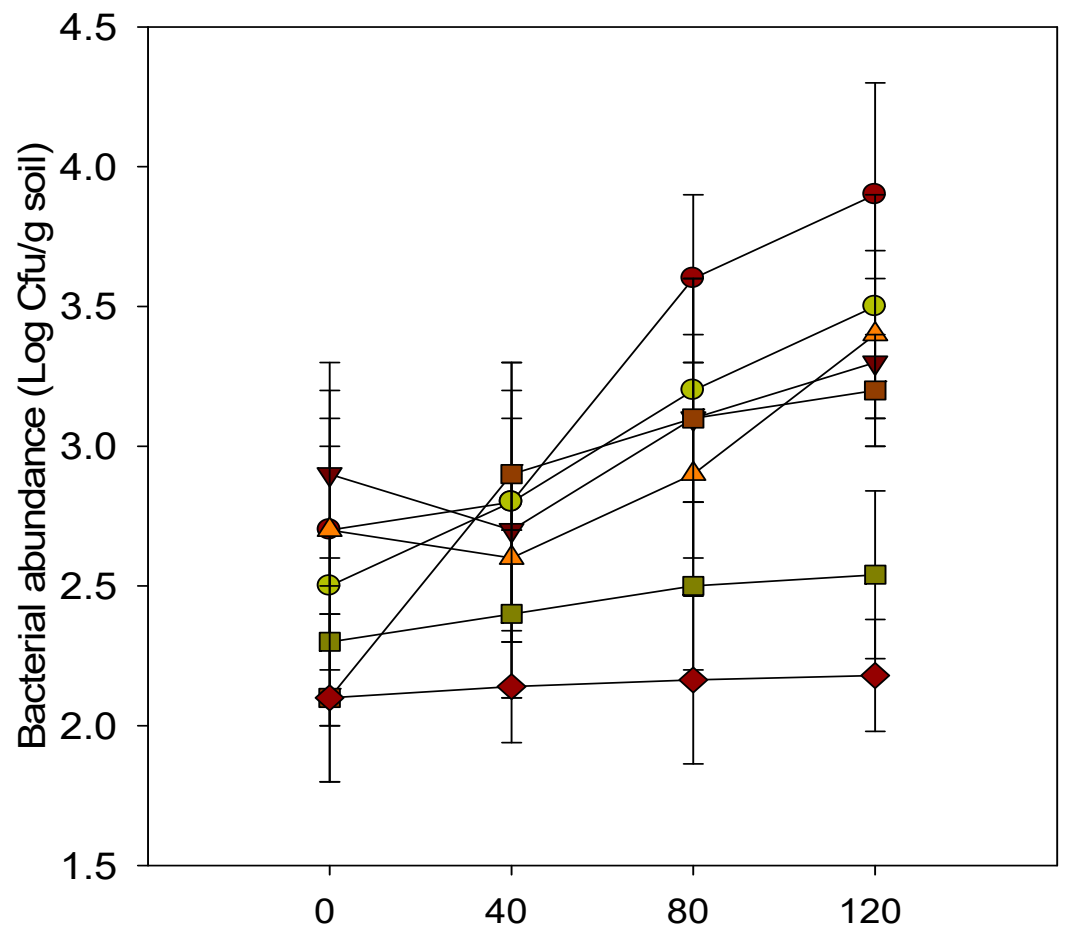

(d)

Figure 4. Cont. 


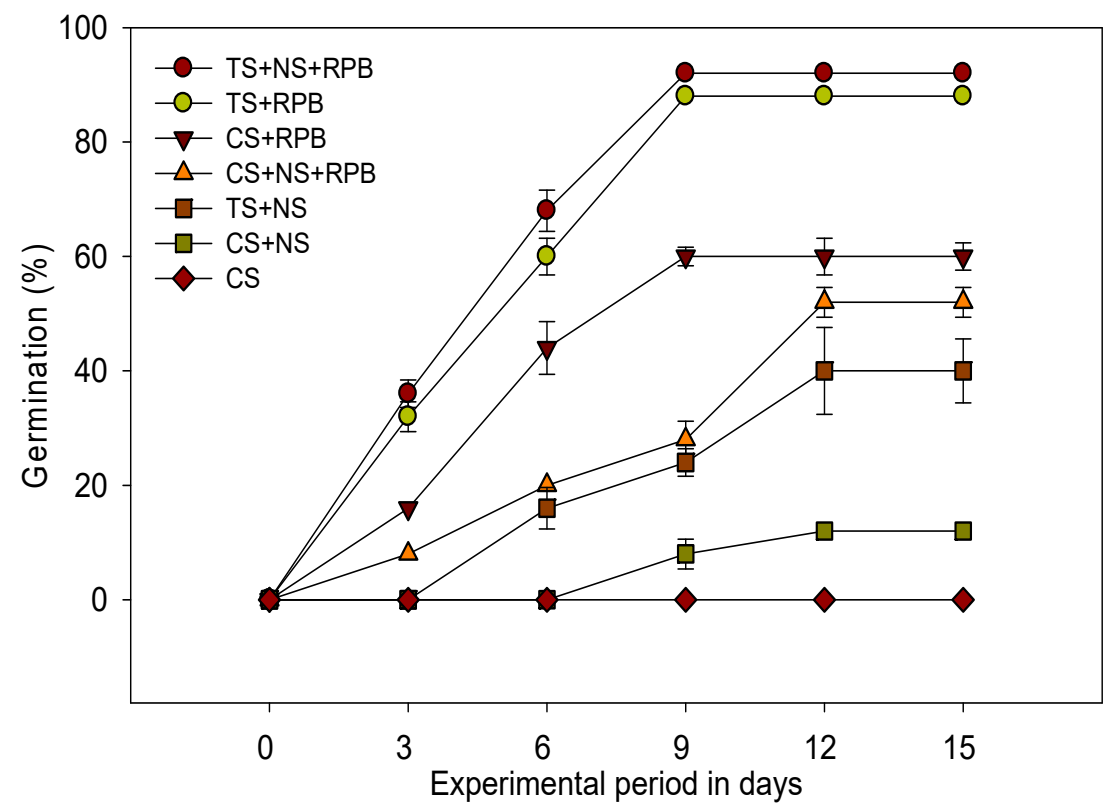

(e)

Figure 4. Reduction in the total petroleum hydrocarbon (TPH, \%) (a) as influenced by different treatments, soil respiration activity $\left(\mathrm{mg} \mathrm{CO}_{2} \mathrm{~g}^{-1}\right.$, soil $\mathrm{h}^{-1}(\mathbf{b})$ and soil dehydrogenase activity $(\mathrm{mg}$ $\mathrm{TPF}^{-1}$ of soil $\mathrm{h}^{-1}$ ) (c). Hydrocarbon-degrading bacterial abundance under different treatments (d) Germination rate (\%) of red pepper seedlings (e) Different lower case letters after values indicate a significant difference at a $p$-value of 0.05 as determined by DMRT.

Phytotoxicity evaluation of treated soils based on germination studies revealed the highest germination (92\%) in the TS + NS + RPB treatment, followed by the TSB + RPB treatment (Figure 4e). These treatments also supported better plant growth in these soils, which was evident by an $86.9 \%$ increase in germination percentage compared to contaminated soil (CS) (Figure S2). Soil respiration and DHA activity are the measures of total microbial activity in soil [52-54], and any change in organic matter quantity or quality can be observed as a change in soil respiration $[54,55]$ and/or in DHA activity [56]. The results of the present study clearly showed that the addition of rhamnolipids improved the activity of Shewanella sp. BS4 and the native soil microbial community, which in turn improved the hydrocarbon bioremediation process. Although the native soil microbes did not play a major role in the bioremediation process, the oil-polluted soil bioremediation was more efficient in the case of the simultaneous application of rhamnolipid and Shewanella sp. BS4.

The results from this study showed that the addition of rhamnolipids might enhance oil biodegradation efficiency by acting as mediators, increasing the mass transfer rate, and thus making oil compounds more bioavailable for soil-indigenous microorganisms. Also, rhamnolipids may induce changes in the properties of cellular membranes of bacteria by enhancing hydrophobicity, which increases microbial adherence [57]. The single-use of rhamnolipids in oil bioremediation may require the addition of nutrients, such as nitrogen or phosphorus, to the soil. For example, the augmentation of rhamnolipids and nutrients enhanced crude oil reduction and increased the abundance and expression of the alkB gene in soil [58].

Our results indicated that the simultaneous application of rhamnolipids and rhamnolipid-producing bacteria enhanced the oil bioremediation process in soil more than the individual use of these treatments. However, the bioaugmentation of oil-polluted soil with the rhamnolipid-producing Shewanella BS4 strain without rhamnolipid amendment provided nearly as effective oil removal efficiency. 
This approach seems especially promising in the case of in situ soil bioremediation, as biosurfactants are produced on-site, and external addition of biosurfactants can be avoided. However, adding bacterial consortia to contaminated soil at field scale always evolves competition with indigenous bacteria and putative loss of inoculum and wanted degradation efficiency, but that will depend on the soil conditions and quality of inoculum in each case. Szulc and co-workers [59] observed that bioaugmentation with a selected consortium of bacterial strains contributed to the highest diesel oil biodegradation efficiency, whereas the addition of rhamnolipids did not notably influence the treatment process in a field-scale study.

Biosurfactants, especially rhamnolipids, can be combined with phytoremediation for effective remediation of polluted soils [60]. Almansoory et al. [61] reported that the application of biosurfactants enhanced the phytoremediation efficiency of gasoline-contaminated soils by up to $93.5 \%$ under pilot-scale conditions.

\section{Conclusions}

In the present study, we adopted a new approach of using rhamnolipids along with rhamnolipid-producing bacteria for the bioremediation of hydrocarbon-contaminated soils. For the first time, a rhamnolipid-producing bacterial stain identified as Shewanella sp. was isolated from polluted soils of Tamil Nadu. Rhamnolipid production by this strain was dependent on the concentration of crude oil, the inoculation load, the temperature, and the $\mathrm{pH}$ of the growth media. Our results confirmed that simultaneous addition of rhamnolipids and a rhamnolipid-producing bacterial stain enhanced soil microbial activity and improved remediation of crude oil-contaminated soil. Though the results of the present study are encouraging, possible success under field conditions always depends upon the ability of the microbial strain to survive under harsh environmental conditions, ability to adapt to grow with the nutrients present under field conditions, and ability to successfully colonize in hydrocarbon-contaminated sites. Future studies at large scale are needed to assess how combined use of rhamnolipids along with rhamnolipid-producing bacteria could be linked to biostimulation and phytoremediation approaches for the treatment of oil-polluted soils. Also, such studies could provide data for performing cost-benefit analysis and life cycle assessment of such combined bioremediation approach.

Supplementary Materials: The following are available online at http:/www.mdpi.com/2076-3417/9/18/3773/s1, Figure S1: Screening of the RhlAB gene with lane 3 representing the strain BS4. Amplification of $842 \mathrm{bp}$ fragment was observed using the primers RhlABf and RhlABr, Figure S2: Photograph of 15-day-old red pepper seedlings under different treatments (no germination was observed in crude oil-contaminated soil with no amendments, and the seeds had a normal $97 \%$ germination rate under normal conditions). Table S1: Experimental central composite design (CCD) runs in design Design-Expert 7.1 and corresponding response (results).

Author Contributions: Conceptualization, M.M.J. and S.T.; methodology, M.M.J., A.B., and S.T.; writing—original draft preparation, M.M.J., S.T., R.G., A.B., D.S., P.R., A.J.H., J.T., and M.T.; writing—review and editing, M.M.J., J.T., and M.T.; funding acquisition, S.T.

Funding: This study was supported by the Estonian Research Council grant PRG548 and EU Horizon 2020 grant No. 679266.

Acknowledgments: The authors are grateful to VELS University for support. The authors also thank the Department of SAIF IIT Guindy, Chennai, India, for FTIR analysis.

Conflicts of Interest: The authors declare no conflict of interest.

\section{References}

1. Abioye, O. Biological remediation of hydrocarbon and heavy metals contaminated soil. In Soil Contamination; Pascucci, Ed.; InTech: Vienna, Austria, 2011; pp. 127-142.

2. Mori, Y.; Suetsugu, A.; Matsumoto, Y.; Fujihara, A.; Suyama, K. Enhancing bioremediation of oil-contaminated soils by controlling nutrient dispersion using dual characteristics of soil pore structure. Ecol. Eng. 2013, 51, 237-243. [CrossRef] 
3. Juhanson, J.; Truu, J.; Heinaru, E.; Heinaru, A. Survival and catabolic performance of introduced Pseudomonas strains during phytoremediation and bioaugmentation field experiment. FEMS Microbiol. Ecol. 2009, 70, 446-455. [CrossRef] [PubMed]

4. Truu, J.; Truu, M.; Espenberg, M.; Nõlvak, H.; Juhanson, J. Phytoremediation and plant-assisted bioremediation in soil and treatment wetlands: A review. Open Biotechnol. J. 2015, 9, 85-92. [CrossRef]

5. Pacwa-Płociniczak, M.; Płaza, G.A.; Piotrowska-Seget, Z.; Cameotra, S.S. Environmental applications of biosurfactants: Recent advances. Int. J. Mol. Sci. 2011, 12, 633-654. [CrossRef] [PubMed]

6. Johnsen, A.R.; Wick, L.Y.; Harms, H. Principles of microbial PAH-degradation in soil. Environ. Pollut. 2005, 133, 71-84. [CrossRef] [PubMed]

7. Banat, I.M.; Franzetti, A.; Gandolfi, I.; Bestetti, G.; Martinotti, M.G.; Fracchia, L.; Smyth, T.J.; Marchant, R. Microbial biosurfactants production, applications and future potential. Appl. Microbiol. Biotechnol. 2010, 87, 427-444. [CrossRef] [PubMed]

8. Müller, M.M.; Kügler, J.H.; Henkel, M.; Gerlitzki, M.; Hörmann, B.; Pöhnlein, M.; Syldatk, C.; Hausmann, R. Rhamnolipids-next generation surfactants? J. Biotechnol. 2012, 162, 366-380. [CrossRef]

9. Liu, H.; Xu, J.; Liang, R.; Liu, J. Characterization of the medium- and long-chain n-alkanes degrading Pseudomonas aeruginosa strain SJTD-1 and its alkane hydroxylase genes. PLoS ONE 2014, 9, e105506. [CrossRef]

10. Ochsner, U.A.; Fiechter, A.; Reiser, J. Isolation, characterization, and expression in Escherichia coli of the Pseudomonas aeruginosa rhlAB genes encoding a rhamnosyltransferase involved in rhamnolipid biosurfactant synthesis. J. Biol. Chem. 1994, 269, 19787-19795.

11. Wittgens, A.; Kovacic, F.; Müller, M.M.; Gerlitzki, M.; Santiago-Schübel, B.; Hofmann, D.; Tiso, T.; Blank, L.M.; Henkel, M.; Hausmann, R.; et al. Novel insights into biosynthesis and uptake of rhamnolipids and their precursors. Appl. Microbiol. Biotechnol. 2016. [CrossRef]

12. Benincasa, M.; Abalos, A.; Oliveira, I.; Manresa, A. Chemical structure, surface properties and biological activities of the biosurfactant produced by Pseudomonas aeruginosa LBI from soapstock. Antonie Leeuwenhoek 2004, 85, 1-8. [CrossRef] [PubMed]

13. Rahman, K.S.M.; Thahira-Rahman, J.; Lakshmanaperumalsamy, P.; Banat, I.M. Towards efficient crude oil degradation by a mixed bacterial consortium. Bioresour. Technol. 2002, 85, 257-261. [CrossRef]

14. Van Dyke, M.I.; Couture, P.; Brauer, M.; Lee, H.; Trevors, J.T. Pseudomonas aeruginosa UG2 rhamnolipid biosurfactants: Structural characterization and their use in removing hydrophobic compounds from soil. Can. J. Microbiol. 1993, 39, 1071-1078. [CrossRef] [PubMed]

15. Hošková, M.; Schreiberová, O.; Ježdík, R.; Chudoba, J.; Masák, J.; Sigler, K.; Rezanka, T. Characterization of rhamnolipids produced by non-pathogenic Acinetobacter and Enterobacter bacteria. Bioresour. Technol. 2013, 130, 510-516. [CrossRef] [PubMed]

16. Rooney, A.P.; Price, N.P.J.; Ray, K.J.; Kuo, T.M. Isolation and characterization of rhamnolipid-producing bacterial strains from a biodiesel facility. FEMS Microbiol. Lett. 2009, 295, 82-87. [CrossRef] [PubMed]

17. Nalini, S.; Parthasarathi, R. Production and characterization of rhamnolipids produced by Serratia rubidaea SNAU02 under solid-state fermentation and its application as biocontrol agent. Bioresour. Technol. 2014, 173, 231-238. [CrossRef] [PubMed]

18. Trögl, J.; Esuola, C.; Kříženecká, S.; Kuráň, P.; Seidlová, L.; Veronesi-Dáňová, P.; Popelka, J.; Babalola, O.; Hrabák, P.; Czinnerová, M.; et al. Biodegradation of High Concentrations of Aliphatic Hydrocarbons in Soil from a Petroleum Refinery: Implications for Applicability of New Actinobacterial Strains. Appl. Sci. 2018, 8, 1855. [CrossRef]

19. Bodour, A.; Miller-Maier, R. Application of a modified drop-collapse technique for surfactant quantitation and screening of biosurfactant-producing microorganisms. J. Microbiol. Methods 1998, 32, 273-280. [CrossRef]

20. Youssef, N.; Duncan, K.; Nagle, D. Comparison of methods to detect biosurfactant production by diverse microorganisms. J. Microbiol. Methods 2004, 56, 339-347. [CrossRef]

21. Morikawa, M.; Hirata, Y.; Imanaka, T. A study on the structure-function relationship of lipopeptide biosurfactants. Biochim. Biophys. Acta Mol. Cell Biol. Lipids 2000, 1488, 211-218. [CrossRef]

22. Cooper, D.; Goldenberg, B. Surface-active agents from two Bacillus species. Appl. Environ. Microbiol. 1987, 53, 224-229.

23. Plaza, G.; Zjawiony, I.; Banat, I. Use of different methods for detection of thermophilic biosurfactant-producing bacteria from hydrocarbon-contaminated bioremediated soils. J. Pet. Sci. Eng. 2006, 50, 71-77. 
24. Eden, P.A.; Schmidt, T.M.; Blakemore, R.P.; Pace, N.R. Phylogenetic Analysis of Aquaspirillum magnetotacticum Using Polymerase Chain Reaction-Amplified 16s rRNA-Specific DNA. Int. J. Syst. Bacteriol. 1991, 41, 324-325. [CrossRef] [PubMed]

25. Wang, Q.; Garrity, G.M.; Tiedje, J.M.; Cole, J.R. Naïve Bayesian Classifier for Rapid Assignment of rRNA Sequences into the New Bacterial Taxonomy. Appl. Environ. Microbiol. 2007, 73, 5261-5267. [CrossRef] [PubMed]

26. Tamura, K.; Peterson, D.; Peterson, N.; Stecher, G.; Nei, M.; Kumar, S. MEGA5: Molecular evolutionary genetics analysis using maximum likelihood, evolutionary distance, and maximum parsimony methods. Mol. Biol. Evol. 2011, 28, 2731-2739. [CrossRef] [PubMed]

27. Chandrasekaran, E.V.; Bemiller, J.N. Constituent analysis of glycosaminoglycans. In Methods in Carbohydrate Chemistry; Academic Press: New York, NY, USA, 1980; Volume 3, pp. 89-96.

28. Rufino, R.D.; de Luna, J.M.; de Campos Takaki, G.M.; Sarubbo, L.A. Characterization and properties of the biosurfactant produced by Candida lipolytica UCP 0988. Electron. J. Biotechnol. 2014, 17, 34-38. [CrossRef]

29. Yakimov, M.M.; Amro, M.M.; Bock, M.; Boseker, K.; Fredrickson, H.L.; Kessel, D.G.; Timmis, K.N. The potential of Bacillus licheniformis strains for in situ enhanced oil recovery. J. Pet. Sci. Eng. 1997, 18, 147-160. [CrossRef]

30. Smyth, T.J.; Perfumo, A.; Mcclean, S.; Banat, I.M. Handbook of Hydrocarbon and Lipid Microbiology; Springer: Berlin/Heidelberg, Germany, 2010; pp. 3687-3704.

31. Sharma, D.; Saharan, B.S.; Chauhan, N.; Procha, S.; Lal, S. Isolation and functional characterization of novel biosurfactant produced by Enterococcus faecium. Springerplus 2015, 4, 1-14. [CrossRef]

32. Yin, H.; Qiang, J.; Jia, Y.; Ye, J.; Peng, H.; Qin, H.; Zhang, N.; He, B. Characteristics of biosurfactant produced by Pseudomonas aeruginosa S6 isolated from oil-containing wastewater. Process Biochem. 2009, 44, 302-308. [CrossRef]

33. Silva, Í.S.; dos Santos, E.D.C.; de Menezes, C.R.; de Faria, A.F.; Franciscon, E.; Grossman, M.; Durrant, L.R. Bioremediation of a polyaromatic hydrocarbon contaminated soil by native soil microbiota and bioaugmentation with isolated microbial consortia. Bioresour. Technol. 2009, 100, 4669-4675. [CrossRef]

34. Benincasa, M. Rhamnolipid produced from agroindustrial wastes enhances hydrocarbon biodegradation in contaminated soil. Curr. Microbiol. 2007, 54, 445-449. [CrossRef] [PubMed]

35. Bekku, Y.; Koizumi, H.; Oikawa, T.; Iwaki, H. Examination of four methods for measuring soil respiration. Appl. Soil Ecol. 1997, 5, 247-254. [CrossRef]

36. Pepper, I.L.; Gerba, C.P.; Brendecke, J. Environmental Microbiology: A Laboratory Manual; Academic Press Inc.: New York, NY, USA, 2000.

37. Peng, S.; Zhou, Q.; Cai, Z.; Zhang, Z. Phytoremediation of petroleum contaminated soils by Mirabilis Jalapa L. in a greenhouse plot experiment. J. Hazard. Mater. 2009, 168, 1490-1496. [CrossRef]

38. Marecik, R.; Biegańska-Marecik, R. Phytoremediation of industrial wastewater containing nitrates, nitroglycerin, and nitroglycol. Polish J. Environ. Stud. 2013, 22, 773-780.

39. Gerdes, B.; Brinkmeyer, R.; Dieckmann, G.; Helmke, E. Influence of crude oil on changes of bacterial communities in Arctic sea-ice. FEMS Microbiol. Ecol. 2005, 53, 129-139. [CrossRef] [PubMed]

40. Rathour, R.; Gupta, J.; Tyagi, B.; Kumari, T.; Thakur, I.S. Biodegradation of pyrene in soil microcosm by Shewanella sp. ISTPL2, a psychrophilic, alkalophilic and halophilic bacterium. Bioresour. Technol. Rep. 2018, 4, 129-136. [CrossRef]

41. Ram, G.; Joe, M.M.; Devraj, S.; Benson, A. Rhamnolipid production using Shewanella seohaensis BS18 and evaluation of its efficiency along with phytoremediation and bioaugmentation for bioremediation of hydrocarbon contaminated soils. Int. J. Phytoremediation 2019, 21, 1-9. [CrossRef] [PubMed]

42. Martín-Gil, J.; Ramos-Sánchez, M.C.; Martín-Gil, F.J. Shewanella putrefaciens in a fuel-in-water emulsion from the Prestige oil spill. Antonie Van Leeuwenhoek 2004, 86, 283-285. [CrossRef] [PubMed]

43. Hassanshahian, M. Isolation and characterization of biosurfactant producing bacteria from Persian Gulf (Bushehr provenance). Mar. Pollut. Bull. 2014, 86, 361-366. [CrossRef] [PubMed]

44. Medina, G.; Juárez, K.; Díaz, R.; Soberón-Chávez, G. Transcriptional regulation of Pseudomonas aeruginosa rhlR, encoding a quorum-sensing regulatory protein. Microbiology 2003, 149, 3073-3081. [CrossRef]

45. Soberón-Chávez, G.; Aguirre-Ramírez, M.; Sánchez, R. The Pseudomonas aeruginosa RhlA enzyme is involved in rhamnolipid and polyhydroxyalkanoate production. J. Ind. Microbiol. Biotechnol. 2005, 32, 675-677. [CrossRef] [PubMed] 
46. Abalos, A.; Maximo, F.; Manresa, M.; Bastida, J. Utilization of response surface methodology to optimize the culture media for the production of rhamnolipids by Pseudomonas aeruginosa AT10. J. Chem. Technol. Biotechnol. 2002, 77, 777-784. [CrossRef]

47. Zhao, F.; Zhou, J.; Han, S.; Ma, F.; Zhang, Y.; Zhang, J. Medium factors on anaerobic production of rhamnolipids by Pseudomonas aeruginosa SG and a simplifying medium for in situ microbial enhanced oil recovery applications. World J. Microbiol. Biotechnol. 2016, 32,1-11. [CrossRef] [PubMed]

48. Box, G.; Hunter, W.; Hunter, J. Statistics for Experimenters; John Wiley \& Sons: New York, NY, USA, 1978.

49. Keeler, S.J.; Hendrickson, E.R.; Hnatow, L.L.; Jackson, S.C. Identification, Characterization, and Application of Shewanella Putrefaciens (LH4:18), Useful in Microbially Enhanced Oil Release. U.S. Patent 7,776,795, 17 August 2010.

50. Heidelberg, J.F.; Paulsen, I.T.; Nelson, K.E.; Gaidos, E.J.; Nelson, W.C.; Read, T.D.; Eisen, J.A.; Seshadri, R.; Ward, N.; Methe, B.; et al. Genome sequence of the dissimilatory metal ion-reducing bacterium Shewanella oneidensis. Nat. Biotechnol. 2002, 20, 1118-1123. [CrossRef] [PubMed]

51. Leitermann, F.; Syldatk, C.; Hausmann, R. Fast quantitative determination of microbial rhamnolipids from cultivation broths by ATR-FTIR Spectroscopy. J. Biol. Eng. 2008, 2, 13. [CrossRef] [PubMed]

52. García-Ruiz, R.; Ochoa, V.; Hinojosa, M.B.; Carreira, J.A. Suitability of enzyme activities for the monitoring of soil quality improvement in organic agricultural systems. Soil Biol. Biochem. 2008, 40, 2137-2145. [CrossRef]

53. Gil-Sotres, F.; Trasar-Cepeda, C.; Leirós, M.C.; Seoane, S. Different approaches to evaluating soil quality using biochemical properties. Soil Biol. Biochem. 2005, 37, 877-887. [CrossRef]

54. Truu, M.; Truu, J.; Ivask, M. Soil microbiological and biochemical properties for assessing the effect of agricultural management practices in Estonian cultivated soils. Eur. J. Soil Biol. 2008, 44, 231-237. [CrossRef]

55. Dilly, O.; Blume, H.P.; Munch, J.C. Soil microbial activities in Luvisols and Anthrosols during 9 years of region-typical tillage and fertilisation practices in northern Germany. Biogeochemistry 2003, 65, 319-339. [CrossRef]

56. Masciandaro, G.; Ceccanti, B.; Ronchi, V.; Bauer, C. Kinetic parameters of dehydrogenase in the assessment of the response of soil to vermicompost and inorganic fertilisers. Biol. Fertil. Soils 2000, 32, 479-483. [CrossRef]

57. Ławniczak, Ł.; Marecik, R.; Chrzanowski, Ł. Contributions of biosurfactants to natural or induced bioremediation. Appl. Microbiol. Biotechnol. 2013, 97, 2327-2339. [CrossRef] [PubMed]

58. Tahseen, R.; Afzal, M.; Iqbal, S.; Shabir, G.; Khan, Q.M.; Khalid, Z.M.; Banat, I.M. Rhamnolipids and nutrients boost remediation of crude oil-contaminated soil by enhancing bacterial colonization and metabolic activities. Int. Biodeterior. Biodegrad. 2016, 115, 192-198. [CrossRef]

59. Szulc, A.; Ambrożewicz, D.; Sydow, M.; Ławniczak, Ł. The influence of bioaugmentation and biosurfactant addition on bioremediation efficiency of diesel-oil contaminated soil: Feasibility during field studies. J. Environ. Manag. 2014, 132, 121-128. [CrossRef] [PubMed]

60. Zhang, J.; Yin, R.; Lin, X.; Liu, W.; Chen, R.; Li, X. Interactive effect of biosurfactant and microorganism to enhance phytoremediation for removal of aged polycyclic aromatic hydrocarbons from contaminated soils. J. Heal. Sci. 2010, 56, 257-266. [CrossRef]

61. Fadhile Almansoory, A.; Abu Hasan, H.; Idris, M.; Sheikh Abdullah, S.R.; Anuar, N. Potential application of a biosurfactant in phytoremediation technology for treatment of gasoline-contaminated soil. Ecol. Eng. 2015, 84, 113-120. [CrossRef]

(C) 2019 by the authors. Licensee MDPI, Basel, Switzerland. This article is an open access article distributed under the terms and conditions of the Creative Commons Attribution (CC BY) license (http://creativecommons.org/licenses/by/4.0/). 